\title{
Pemanfaatan Media Sosial Instagram dalam Mempromosikan Batik Tusta (Studi Kasus Akun Instagram @ Batiktusta)
}

\author{
Novianto Phangestu, Eko Harry Susanto \\ Novianto.915160139@stu.untar.ac.id,Ekos@fikom.untar.ac.id
}

Fakultas Ilmu Komunikasi Universitas Tarumanagara

\begin{abstract}
The development of technology and the internet have given birth to social media, which people today use as a medium of communication, obtaining information, socializing and doing businesses. Social media has brought changes to the world of marketing, especially promotions and advertising that result in the creation of online business trends. Batik Tusta is a brand of batik clothing that was once sold in stores and then experienced a decline in sales and all the stores finally were closed down. On 27 January 2017, Batik Tusta started to market their products online. Since then, Batik Tusta began to grow because it was marketed online and on Instagram as their main promotional tools. The aim of this study is to investigate Batik Tusta's promotional activities on social media Instagram. The concept used in the research is promotion in marketing communication theory. This study uses a qualitative approach with a case study method. The data collection methods used are interviews, observation, documentation and litrature studies. The results show that promotional activities on Instagram Batik Tusta cover interesting uploads and the uses of features provided by Instagram to interact with followers. Batik Tusta also endorses artists and influncers on Instagram, uses Instagram ads everyday, and offers sales promotions to attract attention of their target market as their promotional activities.
\end{abstract}

Keywords: instagram batik tusta, marketing communication, promotion.

\begin{abstract}
Abstrak
Perkembangan teknologi dan internet melahirkan media sosial yang saat ini, hampir semua orang menggunakannya sebagai media dalam berkomunikasi, memperoleh informasi, bersosialisasi dan berbisnis. Media sosial menciptakan perubahan pada dunia pemasaran khususnya promosi dan periklanan yang mengakibatkan terciptanya tren bisnis online. Batik Tusta merupakan merek pakaian batik yang dulunya dijual di toko-toko dan kemudian mengalami penurunan penjualan dan toko yang dulunya ada beberapa semuanya tutup, namun pada tanggal 27 januari 2017 Batik Tusta di pasarkan secara online, Batik Tusta mulai mengalami perkembangan karena dipasarkan secara online dan menggunakan media sosial Instagram sebagai alat promosi utamanya. Tujuan penelitian ini untuk mengetahui bagaimana kegiatan promosi Batik Tusta di media sosial Instagram. Konsep yang digunakan dalam penelitian ini adalah konsep promosi dalam teori komunikasi pemasaran. Penelitian ini menggunakan pendekatan kualitatif dengan metode studi kasus. Sedangkan metode pengumpulan data yang digunakan yaitu wawancara, observasi, dokumentasi, dan studi kepustakaan. Hasil dari penelitian ini adalah kegiatan promosi di Instagram Batik Tusta berasal dari unggahan konten yang menarik dan pemanfaatan fitur yang disediakan Instagram untuk berinteraksi dengan pengikutnya, Batik Tusta juga meng-endorse artis dan influencer di Instagram, kemudian menggunakan Instagram ads setiap harinya, dan promosi penjualan, untuk menarik perhatian target pasarnya.
\end{abstract}

Kata Kunci: instagram batik tusta, komunikasi pemasaran, promosi, 


\section{Pendahuluan}

Perkembangan teknologi dan internet melahirkan media sosial yang saat ini hampir di semua masyarakat menggunakannya sebagai media dalam berkomunikasi, memperoleh informasi, bersosialisasi dan masih banyak lagi. Media sosial menjadi semakin berkembang, karena media sosial dapat digunakan tanpa hambatan waktu, batas geografis, faktor sosial-kultural dan psikografis lain.

Dalam berbagai kemudahan yang ditawarkan oleh media sosial membuat perubahan pada dunia pemasaran yaitu promosi dan periklanan. Sifat internet yang dinamis dan fleksibel membuat pelaku bisnis sering menggunakan berbagai programprogram Public Relations. Penerapan internet pada kegiatan Public Relations memiliki keuntungan, seperti informasi yang disampaikan kepada khalayak. Selain itu, penggunaan internet juga dapat memberikan kesempatan terjadinya hubungan komunikasi bidang pemasaran secara langsung (Ardianto et. al, 2012).

Aktivitas Public Relations yang dilakukan secara online dengan internet disebut juga sebagai digital Public Relations atau Cyber PR. Dalam digital PR semua kegiatan yang dilakukan adalah menjalin hubungan baik dengan masyarakat melalui media sosial atau internet. Digital PR merupakan kegiatan yang paling efektif dalam menjaga hubungan dengan pelanggan, membangun reputasi, serta melakukan kegiatan promosi seperti kegiatan dalam memperkenalkan batik sebagai ciri khas Bangsa Indonesia.

Di Indonesia batik dipercaya sudah ada sejak zaman Majapahit, dan menjadi sangat populer akhir abad XVIII atau awal abad XIX. Batik yang dihasilkan sampai abad XX semuanya adalah batik tulis dan batik cap baru dikenal setelah perang dunia I atau sekitar tahun 1920-an. Kata "batik" berasal dari bahasa Jawa, dan kehadiran batik sendiri di Jawa tidaklah tercatat. G.P Rouffaer berpendapat bahwa teknik batik ini kemungkinan diperkenalkan dari India atau Srilangka pada abad ke-6 atau ke-7. Semenjak industrialisasi dan globalisasi, yang memperkenalkan teknik otomatisasi, batik jenis baru muncul, dikenal sebagai batik cap dan batik cetak sementara tradisional yang diproduksi dengan teknik tulisan tangan menggunakan canting dan malam disebut batik tulis (Lestari, 2012).

Pekalongan menjadi salah satu produsen batik yang banyak dikenal. Kota Pekalongan memiliki julukan yang cukup nyentrik yaitu kota batik Pekalongan, hingga membuat kota tersebut masuk kedalam jaringan kota kreatif UNESCO dalam kategori crafts \& folk art pada akhir tahun 2014 serta mempunyai city branding yaitu world's city of batik. Sesuai dengan namanya, batik Pekalongan merupakan salah satu jenis batik yang dibuat oleh masyarakat Pekalongan. Para pengrajinnya mayoritas tinggal di wilayah pesisir utara pulau Jawa (Iswara, Helen. 2011). Batik Pekalongan semakin berkembang karena adanya para pelaku bisnis yang menggunakan media sosial sebagai sarana promosi.

Saat ini hampir semua perusahaan atau pun pelaku bisnis menggunakan media sosial dalam mempromosikan produknya, salah satu contohnya adalah Batik Tusta. Tren belanja online, melahirkan banyak pebisnis online dengan omzet ratusan juta. Salah satunya adalah Andri Firmansyah, pemilik dari Batik Tusta. Pada tahun 2017, Andri Firmansyah diajak temannya menggarap lagi Batik Tusta yang sudah lima tahun mati suri. Andri Firmansyah memperoleh bahan batik dari Pekalongan, Andri Firmansyah mengganti segmentasi dari Batik Tusta dan model baju keluaran Batik Tusta serta memanfaatkan semua fitur pemasaran online untuk mengembangkan usaha Batik Tusta. 
Batik Tusta merupakan merek pakaian batik yang dulunya dijual di toko-toko dan kemudian mengalami penurunan penjualan dan toko yang dulunya ada beberapa semuanya tutup, namun pada tanggal 27 januari 2017 Batik Tusta dipasarkan secara online, Batik Tusta mulai mengalami perkembangan karena dipasarkan secara online dan menggunakan media sosial Instagram sebagai alat promosi utamanya. Rumusan masalah pada penelitian ini adalah bagaimana pemanfaatan media sosial Instagram dalam mempromosikan Batik Tusta. Tujuan penelitian ini, untuk mengetahui bagaimana kegiatan promosi yang dilakukan Batik Tusta di media sosial Instagram.

Batik Tusta mengalami perkembangan dikarenakan komunikasi pemasaran yang dilakukan Batik Tusta di media sosial Instagram. Komunikasi pemasaran menurut Priansa (2017) adalah aktivitas pemasaran yang menggunakan teknik-teknik komunikasi yang bertujuan memberikan informasi perusahaan dan produk terhadap target pasarnya.

Priansa (2017) mengatakan komunikasi pemasaran memiliki tiga tujuan utama, yaitu memberikan informasi (komunikasi informatif), mempengaruhi agar melakukan pembelian atau menarik perhatian konsumen (komunikasi persuasif) dan mengingatkan khalayak untuk melakukan pembelian ulang (komunikasi mengingatkan kembali).

Bauran pemasaran menurut Kotler dan Keller (dalam Priansa, 2017) adalah kumpulan alat pemasaran yang terdiri dari empat komponen yaitu produk, harga, tempat, dan promosi yang digunakan perusahaan untuk memperoleh respon yang diinginkannya di pasar sasaran. Kotler dan Keller (dalam Priansa, 2017) menjelaskan empat komponen dalam bauran pemasaran, yakni sebagai berikut:

a) Produk (Product)

Produk berupa barang dapat dibeda-bedakan atau diklasifikasikan menurut macam. Kualitas produk menunjukan kemampuan sebuah produk dalam menjalankan fungsinya, ciri produk merupakan sarana kompetitif untuk membedakan produk perusahaan dengan kompetitor, sedangkan desain dapat menyumbangkan kegunaan atau manfaat produk serta coraknya. Dengan demikian, produk barang tidak hanya fokus pada penampilan, tetapi juga berupa produk yang sederhana, aman, tidak mahal, dan ekonomis dalam proses produksi dan distribusinya.

b) Harga (Price)

Sistem manajemen perusahaan akan menetapkan harga dasar yang tepat bagi produk atau jasa yang dihasilkan oleh perusahaan atau pemasar dan harus menentukan strategi yang sesuai dengan berbagai potongan harga, pembayaran biaya, pengangkutan (transportasi), serta sebagai variabel biaya lain yang terkait. Harga adalah sejumlah nilai yang ditukarkan konsumen dengan manfaat menggunakan atau memiliki produk yang nilainya ditentukan oleh penjual untuk satu harga yang sama terhadap semua pembeli.

c) Distribusi (Place)

Sebagian besar produsen menggunakan perantara pemasaran dalam memasarkan produk, khususnya barang dengan cara membangun saluran distribusi, yaitu sekelompok organisasi yang saling tergantung dalam keterlibatan mereka untuk sebuah proses yang memungkinkan suatu produk tersedia bagi penggunaan atau konsumsi oleh konsumen atau pengguna industrial. 


\section{d) Promosi (Promotion)}

Pemasaran tidak hanya membicarakan produk, harga produk, dan mendistribusikan produk, tetapi juga mengkomunikasikan produk kepada masyarakat supaya produk itu dikenal dan mereka bersedia membeli produk tersebut.

\section{Metode Penelitian}

Penelitian ini bertujuan untuk mengetahui bagaimana cara Batik Tusta memanfaatkan media sosial Instagram dalam mempromosikan produknya khususnya dalam meningkatkan kesadaran merek dan penjualannya. Guna memenuhi tujuan penelitian tersebut, maka penulis menggunakan metode penelitian yang disesuaikan dengan masalah yang diteliti.

Pendekatan penelitian yang digunakan pada penelitian ini adalah pendekatan kualitatif. Gunawan (2014) mengatakan pendekatan kualitatif terfokus pada analisis proses dari berpikir secara induktif sesuai dengan dinamika hubungan antar fenomena yang diamati dan senantiasa menggunakan logika ilmiah.

Sedangkan untuk metode penelitian yang digunakan penulis adalah studi kasus. Studi kasus menurut Creswell (dalam Gunawan, 2014) adalah penelitian yang digunakan pada suatu objek, yang dikatakan sebagai kasus, yang dilakukan secara seutuhnya, menyeluruh dan mendalam dengan menggunakan berbagai sumber data. Studi kasus dalam penelitian ini digunakan untuk menguji teori, menjelaskan penyebab kejadian, dan menjawab permasalahan penelitian yaitu mengetahui bagaimana pemanfaatan media sosial Instagram dalam mempromosikan Batik Tusta.

Subjek utama dari penelitian ini adalah pemilik dari Batik Tusta, sosial media officer Batik Tusta, dan pengamat media sosial sekaligus content creator media sosial, serta tujuh informan umum yang merupakan pelanggan dan pengikut Instagram Batik Tusta. Sedangkan objek penelitian pada penelitian ini adalah media sosial Instagram Batik Tusta dalam upaya mempromosikan Batik Tusta.

Metode pengumpulan data yang digunakan penulis adalah metode observasi, wawancara, dokumentasi, dan studi kepustakaan. Penulis melakukan Observasi pada media sosial Instagram Batik Tusta dan mewawancarai pemilik dari Batik Tusta, sosial media officer Batik Tusta, dan pengamat media sosial sekaligus content creator Youtube dan pebisnis online, serta tujuh informan umum yang merupakan pelanggan dan pengikut Instagram Batik Tusta.

Untuk mendapatkan informasi mengenai kegiatan promosi yang dilakukan Batik Tusta di media sosial Instagram dan dampak yang diperoleh setelah menggunakan media sosial Instagram sebagai media promosi utama. Studi kepustakaan dilakukan dengan mengumpulkan informasi dan data melalui jurnal ilmiah, buku-buku referensi dan bahan-bahan publikasi yang tersedia di perpustakaan. Dokumentasi merupakan data pendukung berupa foto atau gambar yang berhubungan dengan penelitian dalam hal ini, penulis mengumpulkan gambar atau foto yang berkaitan dengan kegiatan promosi yang dilakukan Batik Tusta di media sosial Instagram.

Penulis menggunakan teknik pengolahan dan analisis data dengan menggunakan reduksi data, penyajian data, dan penarikan kesimpulan atau verifikasi. Penulis mengumpulkan informasi dan data dari berbagai sumber dengan cara melakukan observasi, wawancara, dokumentasi, dan studi kepustakaan. Setelah semua data telah berhasil dikumpulkan, maka penulis akan mereduksi data yaitu mengolah, 
merangkum, memilah hal-hal yang pokok, memfokuskan pada hal-hal yang penting, dicari tema dan polanya serta dengan demikian data yang telah direduksi akan memberikan gambaran yang lebih jelas dan mempermudah penulis memahami data sehingga tidak kesulitan dalam melakukan pengumpulan data selanjutnya. Penyajian data yang telah diperoleh dapat dijadikan acuan untuk menarik kesimpulan mengenai kegiatan promosi yang dilakukan Batik Tusta menggunakan media sosial Instagram.

\section{Hasil Penemuan dan Diskusi}

Konten yang diunggah pada Instagram Batik Tusta merupakan kegiatan komunikasi pemasaran yang dilakukan Batik Tusta kepada pelanggan dan pengikutnya di media sosial Instagram, hal ini bertujuan untuk memberikan informasi mengenai Batik Tusta kepada pelanggan dan pengikutnya di media sosial Instagram.

Sesuai dengan teori komunikasi pemasaran, Priansa (2017) menjelaskan komunikasi Pemasaran adalah aktivitas pemasaran dengan menggunakan teknikteknik komunikasi yang bertujuan memberikan informasi perusahaan terhadap target pasarnya. Komunikasi pemasaran yang sering terjadi pada Instagram Batik Tusta biasanya berhubungan dengan orang-orang yang ingin memesan produk Batik Tusta dan ingin mengetahui informasi produk dari Batik Tusta.

Untuk menciptakan hubungan yang baik harus didasari dengan komunikasi yang baik, karena dengan adanya komunikasi yang baik antara pelanggan dan penjual akan menciptakan rasa nyaman dan percaya yang diperoleh dari pelayanan yang diberikan. Sesuai dengan tujuan komunikasi pemasaran yang disampaikan oleh Priansa (2017) tujuan komunikasi pemasaran ada tiga yaitu komunikasi informatif, komunikasi persuasi, komunikasi mengingatkan kembali.

Komunikasi pemasaran yang dilakukan melalui media sosial Instagram Batik Tusta bertujuan untuk memberikan informasi mengenai jam operasional dari Batik Tusta, menginformasikan mengenai produk-produk yang tersedia, berinteraksi dengan pelanggan dari Batik Tusta agar terjalin hubungan yang baik, membangun kepercayaan pelanggan terhadap produk yang dijual Batik Tusta, kemudian memberikan motivasi dan tips sukses dalam dunia kerja.

Konten yang dibuat Batik Tusta di media sosial Instagram bertujuan untuk mencari engagement, konten yang diunggah tidak selalu tentang jualan, Batik Tusta perlu meningkatkan engagement karena algoritma Instagram mencari akun yang engagementnya bagus. Konten yang diunggah oleh Instagram Batik Tusta untuk menarik perhatian pengikut dan pelanggannya yaitu giveaway, konten edukasi, endorse, motivasi, tips dalam dunia kerja, informasi seputar produk dan konten tentang kepedulian Batik Tusta kepada pedagang kecil yang ada di IGTV yang dibuat secara menarik dan juga gaya hidup dari target pasarnya yang dijadikan konten serta Batik Tusta membangun kepercayaan pelanggan dan pengikutnya dengan mengunggah konten-konten yang diunggah oleh pelanggan dan pengikutnya yang memberikan testimoni pada produknya.

Batik Tusta pada awalnya menemukan beberapa kendala seperti dalam membangun traffic yang ada pada media sosial Instagram Batik Tusta, mencari market pada media sosial Instagram, membuat konten dan materi promosi, serta pengembangan motif batik yang diproduksi oleh Batik Tusta. Untuk mengatasi kendala tersebut, bauran pemasaran yang dimiliki oleh Batik Tusta harus jelas dan tepat dalam menjangkau target pasarnya. Bauran pemasaran menurut Kotler dan Keller (dalam Priansa, 2017) adalah kumpulan alat pemasaran yang terdiri dari empat 
komponen yaitu produk, harga, tempat, dan promosi yang digunakan perusahaan untuk menghasilkan respon yang diinginkannya di pasar sasaran.

Batik Tusta meningkatkan kesadaran penggunaan pakaian Batik di lingkungan masyarakat melalui unggahan foto dan video yang menarik tentang penggunaan pakaian batik dan membuat beberapa campaign untuk mengajak masyarakat menggunakan batik, salah satu campaign Batik Tusta adalah selalu mengajak masyarakat dan pengikutnya untuk memakai batik melalui caption dan hastag \#ayopakaibatik \#batikkubatiktusta. Batik Tusta membuat konten yang menjelaskan mengenai proses dalam membuat pakaian batik, agar masyarakat bisa menghargai setiap proses yang ada dalam membuat batik dan mulai ikut serta melestarikan batik. Batik Tusta juga memiliki konten mengenai kegiatan sosial yang membantu pedagang kecil dan memberikan produk pakaian batik dari Batik Tusta pada pedagang kecil tersebut, hal ini merupakan kepedulian Batik Tusta terhadap peningkatan kesadaran masyarakat dalam menggunakan batik.

\section{Simpulan}

Berdasarkan penelitian yang telah dilakukan oleh penulis, maka dapat disimpulkan, peningkatan penjualan dan perkembangan merek yang diperoleh Batik Tusta terletak pada interaksi yang aktif melalui media sosial Instagram dan konsisten dalam membuat konten-konten yang menarik di media sosial Instagram serta pemanfaatan fitur-fitur yang tersedia pada Instagram dalam melakukan kegiatan promosi seperti menggunakan Instagram ads setiap harinya sehingga menciptakan engagement yang meningkatkan traffic pada Instagram Batik Tusta. Dari hasil wawancara penulis terhadap pelanggan dan pengikut Instagram Batik Tusta, sebagian besar pelanggan dan pengikut Instagram Batik Tusta mengetahui Batik Tusta dari penggunaan Instagram ads atau iklan berbayar di Instagram dan Batik Tusta memang lebih fokus pada penggunaan Instagram $a d s$ dalam melakukan promosi dibandingkan dengan kegiatan promosi lainnya, karena Instagram ads memiliki dampak yang besar dalam menjangkau target pasar. Hal ini sesuai dengan pernyataan dari pemilik Batik Tusta dan sosial media officer Batik Tusta, yang diperoleh dari hasil wawancara penulis.

\section{Ucapan Terima Kasih}

Penulis mengucapkan terima kasih kepada semua pihak yang telah membantu penulis, khususnya kepada dosen Fikom Untar, pemilik dari Batik Tusta yaitu bapak Andri Firmansyah yang sudah mengizinkan penulis dalam melakukan penelitian pada merek Batik Tusta, kemudian semua informan atau narasumber yang sudah bersedia membantu penulis dalam memberikan informasi, dan keluarga serta teman-teman penulis yang telah memberi dukungan dan motivasi kepada penulis sehingga penulis dapat menyelesaikan penelitian ini.

\section{Daftar Pustaka}

Ardianto, Elvinaro et. al. (2012). Komunikasi Massa: Suatu Pengantar. Bandung: Simbiosa Rekatama Media.

Azeharie, S., \& Sari, W. (2015). Penyikapan Diri Ibas Yudhoyono Dalam Instagram Dan Reaksi Ani Yudhoyono Terhadap Postingan Instagram Ibas. Jurnal 
Novianto Phangestu, Eko Harry Susanto: Pemanfaatan Media Sosial Instagram dalam Mempromosikan Batik Tusta (Studi Kasus Akun Instagram @Batiktusta)

Komunikasi, $\quad$ Vol. $\quad 7, \quad$ No. 1, Hal 108-107. https://journal.untar.ac.id/index.php/komunikasi/article/view/11/32

Gunawan, Imam. (2014). Metode Penelitian Kualitatif: Teori dan praktik. Jakarta: PT Bumi Aksara.

Lestari, Suema Dwi. (2012). Mengenal Aneka Batik. Jakarta: PT Balai Pustaka (Persero).

Liliweri, Alo. (2011). Komunikasi Serba Ada Serba Makna. Jakarta: Kencana Prenada Media Group.

Priansa, Doni. (2017). Komunikasi Pemasaran Terpadu Pada Era Media Sosial. Bandung: CV PUSTAKA SETIA.

Riska, Marlinda. (2019, agustus 24). Kisah Andri Firmansyah, dari ekspor ikan hingga sukses berbisnis batik. Retrieved Agustus 31, 2019, from kontan.co.id Online: https://peluangusaha.kontan.co.id/news/kisah-andri-firmansyah-dari-eksporikan-hingga-sukses-berbisnis-batik?page $=3$

Sugiyono. (2014). Memahami Penelitian Kualitatif. Bandung: Alfabeta, CV. 